\title{
18. Protecting the rights of future generations through climate litigation: lessons from the struggle against deforestation in the Colombian Amazon
}

\section{Camila Bustos, Valentina Rozo-Ángel and Gabriela Eslava-Bejarano}

In 2017, a group of 25 children and young people from 17 cities in Colombia filed a lawsuit against the state for failing to stop deforestation in the Amazon region. The plaintiffs come from some of the cities and towns most vulnerable to climate change in the country, ranging from coastal areas to high altitudes. They all rely on their environment for their daily activities and have seen a range of their human rights threatened by increasing deforestation in the Amazon region. With the support of the Center for the Study of Law, Justice, and Society (Dejusticia), the plaintiffs came together to file a tutela action, a special kind of legal mechanism to protect fundamental rights. They claimed that the high deforestation rate in the country and its connection with climate change was threatening their right to life, health, water, and food and violating their right to a healthy environment. In doing so, they joined a global movement demanding action on climate change from national governments.

According to the Institute of Hydrology, Meteorology and Environmental Studies (IDEAM), the state agency tasked with producing environmental data in the country, the main source of greenhouse gas (GHG) emissions in Colombia is deforestation. The most recent national inventory indicates that 36 percent of emissions come from deforestation alone. ${ }^{1}$ At the time of filing, deforestation rates had increased 44 percent between 2016 and 2017, ${ }^{2}$ with over 40 percent of early deforestation warnings located in the Amazon region. ${ }^{3}$

While climate change impacts are already being felt throughout the country, future generations of Colombians will disproportionately face the burden of climate impacts as a result of emissions today. During the period 2041-70, Colombia will experience a $1.6^{\circ} \mathrm{C}$ increase in average temperatures and a range of impacts including changes in rainfall patterns, droughts, and severe 
flooding. In addition, plaintiffs living on the Atlantic and Pacific coasts are likely to face an increase in sea level rise, while plaintiffs located in the capital city of Bogotá may see their main source of potable water - a high-elevation ecosystem known as paramo - threatened by water shortages resulting from deforestation. ${ }^{4}$ Based on these climate change scenarios, the lawsuit defines "future generations" as those who will be adults during this period, but who currently are not old enough to occupy a high rank in government or to be taken seriously in the decision-making process. In light of this fact, the lawsuit centers intergenerational equity in the plaintiffs' demands.

\section{THE LEGAL OBLIGATION TO STOP DEFORESTATION}

According to the National Development Plan (2014-18), ${ }^{5}$ the Colombian government had set the goal of limiting deforestation to 90000 hectares by the end of 2018. Nevertheless, by 2017, deforestation was already twice this amount (178 000 hectares). Furthermore, Colombia committed to reduce its emissions by 20 percent by 2030 based on a business-as-usual scenario as part of its Nationally Determined Contribution (NDC) in the context of the Paris Agreement. Prior to this, the state also signed a cooperation agreement with Germany, Norway, and the United Kingdom to reduce deforestation in the Amazon to net zero by 2020. Despite all these national and international commitments, deforestation rates had continued to increase by the time the plaintiffs filed the lawsuit; approximately 66.2 percent of deforestation was concentrated in the Amazon region. In addition to these commitments, the Colombian government is bound by the national Constitution, which includes a provision on the right to enjoy a healthy environment and to participate in the environmental decision-making process. The Constitution also protects the fundamental right to life, health, food, and water.

The plaintiffs alleged that these fundamental rights were threatened by increasing deforestation. Deforestation contributes GHG emissions because the forest acts as a carbon sink. It also disrupts key ecosystem services like water cycle regulation that affect people across the country. In this sense, government inaction contributes to the climate crisis. All the towns and municipalities where the plaintiffs come from are vulnerable to climate impacts and each individual plaintiff faces concrete threats to their rights, depending on their location and lifestyle. Despite the fact the climate change is a multi-causal problem, deforestation is the main contributor to GHG emissions in Colombia.

The lawsuit also invoked five legal principles enshrined in the Constitution or in international environmental treaties that have been ratified by Colombia. The precautionary principle was applicable insofar as plaintiffs sought to prevent the realization of an irreversible harm. The rise of GHG emissions resulting from deforestation and the link between an increase in the frequency 
and intensity of natural disasters and the deforestation rate in the Colombian Amazon served as evidence of the imminent threat posed by the climate crisis. In addition, the principle of intergenerational equity within the framework of sustainable development sets the ground for the plaintiffs' claims, who will suffer the consequences of the decisions made today if current generations fail to act on deforestation and climate change. Similarly, the principle of the priority of children's' interests and well-being ought to serve as a key consideration when making decisions that will directly impact the rights of children, while the principle of public participation gives voice to young people in decision-making processes that will directly affect their future. Finally, the solidarity principle enshrined in Colombian and international law requires that the government and citizens consider and incorporate the public interest and how actions will have a beneficial or detrimental impact on others into their decision-making process. Together, the lawsuit asked the Court to interpret and apply these principles when reaching a decision.

\section{THE SUPREME COURT RULES ON THE SIDE OF FUTURE GENERATIONS}

In March 2017, the Superior Tribunal of Bogotá ruled against the plaintiffs, arguing that the tutela mechanism was not the appropriate vehicle for their claims since the right to healthy environment is not a fundamental right, but a collective one. ${ }^{6}$ After losing in the Court of First Instance, the plaintiffs appealed the decision. On April 5, the Supreme Court ruled in favor of the plaintiffs, holding that the Colombian government was in fact threatening their constitutionally protected rights.

In the ruling, the Court found that the omissions of the Presidency of the Republic, the Ministry of Environment and Sustainable Development, and the Ministry of Agriculture and Rural Development, as well as the mayors of the Amazon region and environmental authorities, constituted a breach of their legal duties. By allowing deforestation in the Amazon, one of the most biodiverse ecosystems in the world, government agencies were violating the right of youth to a healthy environment. Since deforestation increases emissions, and in turn contributes to an increase in global temperature, the government has an obligation to address the problem. Likewise, the Court acknowledged that the omissions of the state to fulfill its already existing commitments threaten the fundamental rights to life, water, health, and food of the plaintiffs, all of whom are likely to be alive during the first scenario of climate change predicted by the IDEAM.

First, the Court ordered the state to create a short-, medium-, and long-term action plan to stop deforestation in the Amazon region. Second, the Supreme Court granted the plaintiffs' petition and ordered the Presidency and the 
Ministries of Environment and Agriculture to create an "intergenerational pact for the life of the Colombian Amazon," with the participation of the plaintiffs, affected communities, and research and scientific organizations. The plan must aim to reduce deforestation to zero and mitigate GHG emissions. Third, the Supreme Court ordered the municipalities of the Amazon to update their Land Management Plans within a five-month period, and to develop an action plan to reduce deforestation to zero. Fourth, the Court ordered the Regional Autonomous Corporations in the Amazon (Corporaciones Autónomas Regionales), the environmental authorities in the region, to issue an action plan to reduce regional deforestation.

In order to protect this vital ecosystem, the Supreme Court also recognized the Colombian Amazon as an "entity subject of rights". This was the second time in the country's history that a court granted nature this type of legal status, after the Constitutional Court designated the Atrato River subject of rights in 2017. This means that the Amazon has the right to be protected, conserved, maintained, and restored. In addition, the Court extended the right to a healthy environment to future generations based on the principle of solidarity and intrinsic value of nature.

\section{THE IMPLEMENTATION OF THE RULING: LESSONS FOR CLIMATE CHANGE LITIGATION AND ADVOCACY ${ }^{7}$}

Traditionally, human rights studies and practice have been more occupied with litigation than on monitoring the implementation of a judicial decision. The same has happened around the world in the emerging field of climate change litigation. To counteract this trend, the plaintiffs and stakeholders in the Colombian case have pushed for compliance with the court ruling. What lessons can be learned for future climate change litigation based on what has happened in Colombia since the Supreme Court issued a favorable decision?

The first lesson is that lawsuits have become an increasingly frequent route for citizens' claims to urgent action on climate change. Since the decision of the Supreme Court, similar decisions have followed. Courts in Australia and the United States have held that the negative impacts of climate change can be the basis for denying licenses to carbon-intensive and oil projects. Dutch courts issued a pioneer ruling in the Urgenda case (see Chapter 15), which obliged the government to commit to a more ambitious and urgent mitigation target. New cases continue to be filed, joining more than 800 cases against both governments that have failed to act in the context of the climate crisis, and fossil fuel companies that have prospered at the expense of global warming. ${ }^{8}$ The evolution of climate litigation has closely followed advances in scientific knowledge. The claim in the Colombian case - like others, such as the case of 
Juliana v. United States (see Chapter 16) - has cited recent climate science, which can now attribute more accurately the link between climate change and extreme weather events, such as floods and heatwaves. ${ }^{9}$

The second lesson is that understanding the impact of this kind of litigation requires taking into account its effects on both public policies and the public sphere. The court ruling in the Colombian Amazon case has until now had more effects on the public sphere than on government action against deforestation and climate change. Together with the efforts of many human rights, indigenous and environmental organizations, our claim and follow-up to the decision contributed by bringing the deforestation of the Amazon to the forefront of public debate. The media continuously monitors the issue and Colombian President Iván Duque declared it one of his priorities in his inauguration speech in 2018. However, promises have not been followed by the difficult decisions required to drastically reduce deforestation, such as the regulation or prosecution of illegal and legal actors who are promoting the colonization of the Amazon for mining and livestock. The good news is that, in 2018, deforestation went down from 219973 to 197159 hectares. ${ }^{10}$ The bad news is that this level is still well beyond what would be needed for Colombia to bring down deforestation to net zero any time soon.

The third lesson is that litigators need to pay close attention to the implementation phase of their efforts, in order to keep the pressure on relevant public officials to comply with courts' orders and prevent governments' opportunistic use of such orders to pursue policies that run against the spirit and orders of judicial decisions. As for the results of implementation efforts in the Colombian case, the balance thus far is mixed. On the one hand, the convergence of various efforts and factors (including the Court's ruling) has contributed to halt deforestation's upward trend, at least temporarily. On the other hand, the government has been hesitant and slow in implementing the Court's orders. Although it published a document called "Action Plan for Reducing Deforestation and Tackling the Effects of Climate Change in the Colombian Amazon - STC 4360 from 2018", compliance with the Court's orders remains challenging. The document was not developed in a participatory way despite the imperative of including the plaintiffs and other stakeholders in the process. Furthermore, the document was based on an existing governmental policy known as the "Integral Strategy for Controlling Deforestation and Managing the Rainforests". The strategy was developed during the eight years prior to the lawsuit and the judgment, with no input from younger generations or the plaintiffs.

As part of the implementation process, the Ministry of Environment also organized seven different workshops at the national and regional level. Although the government claimed that there had been active plaintiff participation, only four plaintiffs were able to attend each of the workshops. Overall, the 
voices of young people were absent from the process in addition to the failure to include other key stakeholders such as small farmers, Afro-Colombians, and indigenous communities. The limited involvement of a range of societal actors has undermined the inclusivity and potential impact of the process.

With regard to the order to develop an intergenerational pact, the Ministry of Environment sent a letter to the Court explaining the progress thus far on the second order. The Ministry submitted the document "Developing Agreements to Guarantee the Life of the Colombian Amazon - Progress in the Development of the Pact" and requested ten extra months for fulfilling the order. A review of the record in April 2019 indicated no evidence of any further advances.

Perhaps in response to the limited participation of young people and local communities in the development of the intergenerational pact, the Ministry of Agriculture launched an online platform for people all over the country to contribute ideas for the development of the document. Nevertheless, the plaintiffs explained that an online tool does not take into account that more than half the poorest households in Colombia do not have internet access. ${ }^{11}$ This severely limits the participation of the people most affected by deforestation, both in the Amazon region and across the country.

The government submitted a draft of the pact that was originally developed by the plaintiffs as a working paper. The document was meant as a starting point and thus was not developed in collaboration with government officials, communities, or scientists, as ordered by the Supreme Court. The plaintiffs had submitted the draft to the Ministry of Environment hoping to receive feedback. Yet, the document was modified without the plaintiffs' permission and submitted to the Court as evidence of compliance with the order.

As for the potential for backlash and the opportunistic use of court orders by recalcitrant governments, the Colombian litigation also offers useful lessons about the need to anticipate risks and blind spots. On several occasions, the Colombian government and the Attorney General's Office have invoked the ruling in order to crack down on small peasants, as opposed to large landowners, cattle ranchers, large-scale loggers and the other powerful actors who are the main drivers of deforestation. Although the government has failed to meaningfully engage with plaintiffs, it has neglected even more local communities in the Amazon region, including indigenous peoples' communities and organizations, who bear the direct impact of deforestation. This is a particularly salient omission in a country that is undergoing a challenging post-conflict process that, albeit putting an end to a five-decade-old armed conflict, has also created new vulnerabilities for the Amazon's inhabitants and ecosystems, as has happened in other countries and regions in the aftermath of civil wars. ${ }^{12}$

Since the will of governments is not enough, the impact of litigation depends on the engagement and mobilization of local communities and citizens. This is the fourth lesson from the case. In the past year, 16-year-old Swedish activist, 
Greta Thunberg started a wave of climate protests. Hundreds of thousands of students and young people, including the plaintiffs of the Colombian lawsuit, have joined her. Litigation led by adults may help, but a more lasting and decisive impact will most likely come from action by youth, who may suffer the most severe effects of an uninhabitable planet.

Litigation and mobilization steered by youth may be the nudge needed to draw the urgent attention that the climate crisis has lacked. After all, as asserted by scientific expert James Hansen in his statement before the Colombian Supreme Court in support of the case, this is a crisis that "may be an unbearable burden to the youth and coming generations".

\section{NOTES}

1. Institute of Hydrology, Meteorology and Environmental Studies (IDEAM) and United Nations Development Programme (UNDP) (2016). National and Departmental Greenhouse Gas Inventory - Colombia: Third National Communication to the United Nations Convention on Climate Change (UNFCCC). Available in Spanish at https://www.undp.org/content/dam/colombia/docs/cop22/ IDEAM_TCNCC_INGEI_WEB.pdf. Accessed August 3, 2019.

2. Institute of Hydrology, Meteorology and Environmental Studies (IDEAM) and United Nations Development Programme (UNDP) (2017). National and Departmental Greenhouse Gas Inventory - Colombia: Third National Communication to the United Nations Convention on Climate Change (UNFCCC): Executive Summary. Available in Spanish at http:/documentacion.ideam.gov.co/ openbiblio/bvirtual/023732/RESUMEN_EJECUTIVO_TCNCC_COLOMBIA .pdf. Accessed August 3, 2019.

3. The IDEAM produces early warnings on deforestation every three months, identifying regional deforestation hotspots. See Boletins de alertas tempranas de deforestación [Deforestation early warning bulletins], Nos. 10, 11 and 12 at http:// www.ideam.gov.co.

4. This type of ecosystem is replenished by rainfall coming from the Amazon. As more forest is cut down, the water cycle is likely to be disrupted.

5. The National Development Plan 2014-18 was codified into law through Ley 1753 of 2015.

6. Under Colombian law, plaintiffs may file a class action known as acción popular to demand the protection of collective rights such as the right to a healthy environment.

7. This section is partially taken from César Rodríguez-Garavito (2019). "Climate change and human rights: lessons from litigation for the Amazon". Openglobalrights.org, April 25. Accessed July 30, 2019, at https://www .openglobalrights.org/climate-change-and-human-rights-lessons-from-litigation -for-the-amazon/.

8. See UN Environment and Sabin Center for Climate Change (2017). The Status of Climate Change Litigation: A Global Review. Accessed August 13, 2020 at https://wedocs.unep.org/bitstream/handle/20.500.11822/20767/climate-change -litigation.pdf? sequence $=1$ \&isAllowed $=\mathrm{y}$. 
9. Sophie Marjanac and Lindene Patton (2018). "Extreme weather event attribution science and climate change litigation: an essential step in the causal chain?" Journal of Energy \& Natural Resources Law, 36 (3), 265-98.

10. El Espectador (2019). "En 2018, Colombia deforestó 197.159 hectáreas de bosque" [In 2018, Colombia deforested 197159 hectares of forest]. Accessed July 30, 2019 at https://www.elespectador.com/noticias/medio-ambiente/se-redujo-la -tasa-de-deforestacion-en-colombia-articulo-870196.

11. Presidencia de la República (2019). Bases del Plan Nacional de Desarrollo 2018-2022 [Bases of the National Development Plan 2018-2022], p. 647. Accessed August 13, 2020 at https://colaboracion.dnp.gov.co/CDT/Prensa/ BasesPND2018-2022n.pdf.

12. César Rodríguez-Garavito, Diana Rodríguez-Franco and Helena Durán (2017). Environmental Peace: Challenges and Proposals after the Peace Accord. Bogotá: Dejusticia. Available in Spanish at https://www.dejusticia.org/publication/la-paz -ambiental-retos-y-propuestas-para-el-posacuerdo-2/. Accessed July 30, 2019. 